\title{
ANTAGONISMO DE BACTÉRIAS LÁTICAS CONTRA Fusarium guttiforme, AGENTE ETIOLÓGICO DA FUSARIOSE DO ABACAXI (Ananas comosus (L.) Merril)
}

\section{$\underline{\text { Débora de Jesus Barbosa }}^{1}$; Elinalva Maciel Paulo²; Hugo Neves Brandão³ ${ }^{3}$ Ilana M. P.Mamédio ${ }^{4}$}

1. Bolsista PIBIC/CNPq, Graduando em Ciências Biológicas, Universidade Estadual de Feira de Santana, e-mail: deborabarbosa.fs@hotmail.com

2. Orientador, Departamento de Biologia, Universidade Estadual de Feira de Santana, e-mail: elinalvamaciel@gmail.com 3. Participante do projeto, Hugo Neves Brandão, e-mail hugohnb@gmail.com

4. Co-orientadora, Departamento de Ciências Biológicas, Universidade Estadual de Feira de Santana, e-mail: ilana_mamedio@hotmail.com

PALAVRAS-CHAVE: Controle biológico, fitopatologia, difusão em disco

\section{INTRODUÇÃO}

O abacaxi (Ananas comosus (L.) Merril) é uma monocotiledônea, da família Bromeliaceae, subfamília Bromeloideae. O Brasil é o segundo maior produtor mundial de abacaxi, e sua principal cultivar plantada é a Pérola e em seguida a Smooth Cayenne. Ambas suscetíveis à fusariose (CUNHA et al., 1999). A fusariose constitui séria ameaça à abacaxicultura mundial, e seu agente causal é o fungo $F$. guttiforme (NIRENBERG; O’DONNELL, 1998). Este patógeno penetra em seus hospedeiros por meio de aberturas naturais ou ferimentos. Podridão dos tecidos afetados acompanhada por exsudação de substâncias gomosas são os principais sintomas da fusariose (MATOS; CABRAL, 2005). Uma das alternativas de controlar a proliferação do Fusarium é através do controle biológico (MICHEREFF, 2001) estando às bactérias láticas como um grupo de micro-organismo que apresenta grande potencial para inibição do crescimento fúngico, devido à sua capacidade de antagonismo, observação esta, que objetiva a realização deste trabalho.

\section{METODOLOGIA}

\section{Isolamento do patógeno}

Os isolamentos de $F$. guttiforme foram obtidos a partir de fragmentos de tecidos retirados de frutos de abacaxi (Ananas sp.) com sintomas da doença. Estes foram colocados em placas de Petri com meio BDA. As placas foram incubadas à temperatura ambiente $(24 \pm$ $20 \mathrm{C})$ e luz constante durante 10 dias. Para fins da avaliação do crescimento dos diferentes 
isolados obtidos, discos de aproximadamente $5 \mathrm{~mm}$ de cada um deles foram posteriormente transferidos para o centro de cinco placas de Petri contendo BDA (SOUZA, 2010).

\section{Identificação}

A caracterização morfológica dos micro-organismos foi realizada através de chaves de identificação, a partir dos atributos macro e micros morfológicos das culturas puras isoladas (NIRENBERG e O`DONNEL, 1998).

\section{Preparo das culturas de bactérias láticas}

Duas espécies de bactérias láticas (Lactobacillus plantarum e Lactobacillus paracasei) isoladas do caldo fermentativo do abacaxi, pertencentes à bacterioteca do LAMASP/UEFS foram reativadas em caldo MRS e incubadas a $30^{\circ} \mathrm{C}$ por 24 horas.

\section{Avaliação da atividade antifúngica das bactérias láticas}

As duas espécies de bactérias láticas foram testados por meio do método de difusão em Agar proposto por Corsetti et al., (1998). Em uma placa de Petri previamente esterilizada foram dispostos $10 \mathrm{~mL}$ de BDA previamente inoculado com a suspensão de propágulos de Fusarium guttiforme a uma concentração de $10^{4}$ propágulos. $\mathrm{mL}^{-1}$, quantificados com o auxílio de Câmera de Neubauer e microscópio de luz. Após a solidificação do meio, as placas foram incubadas em estufa tipo B.O.D. por $22^{\circ} \mathrm{C}$ durante 24 horas. Após esse período foi disposto sobre a superfície do Ágar discos de papel de filtro $\mathrm{n}^{\circ} 1$ estéreis, apresentando $5 \mathrm{~mm}$ de diâmetro. Foram aplicados $100 \mu \mathrm{L}$ de suspensão bacteriana, após o líquido ser fixados pelos discos as placas retornarão à B.O.D. por $22^{\circ} \mathrm{C}$ durante 10 dias. Também foi realizado o teste controle, onde os discos acrescentados na placa não continham inoculante. As placas foram observadas, e os halos de inibição mensurados com auxílio de uma régua milimetrada. A suspensão de propágulos foi feita a multiplicação de Fusarium guttiforme em tubos contendo meio BDA (bisel longo) incubados a $22^{\circ} \mathrm{C}$ por 7 dias. $\mathrm{O}$ inoculo de propágulos foi preparado através de suspensão de conídios em solução salina a 0,85\%: Tween 80 (9:1, v/v) agitando em Vortex por 5 minutos. Após agitação, o conteúdo líquido foi transferido para tubos de vidro estéreis. A determinação da concentração de propágulos foi realizada por contagem com auxílio de uma câmara de Neubauer e microscópio de luz, com um aumento óptico de 400 vezes. A suspensão bacteriana foi preparada utilizando culturas bacterianas láticas previamente armazenadas sob refrigeração ou congeladas. Estes foram reativados e 
incubados a $30^{\circ} \mathrm{C}$ por 48 horas. O volume necessário de caldo MRS inoculado foi transferido a um tubo contendo MRS estéril até que essa suspensão se ajuste ao tubo 10 da escala de Mac Farland, o que corresponde à uma concentração de 3,0 x $10^{9}$ UFC. $\mathrm{mL}^{-1}$.

\section{RESULTADOS E DISCUSSÃO}

\section{Isolamento e identificação de Fusarium guttiforme}

Os isolados de Fusarium guttiforme, enumerados de I1 a I6, apresentaram bom crescimento com a temperatura de incubação na faixa de $24 \pm 20^{\circ} \mathrm{C}$ e coloração com variação de alaranjado a violeta. Constatou-se nos isolados a ausência de clamidósporos e a presença de macroconídeos sob a forma delgada e ligeiramente alongada, e de microconídeos em formato ovoide conforme, conforme aspectos apontados por Nirenberg; O’Donnell (1998).

\section{Teste de antagonismo}

Em meio BDA e na presença da bactéria Lactobacillus plantarum, observou-se a variação do tamanho dos halos de 8,6 a 10,0mm. Já na presença da bactéria Lactobacillus paracasei e no mesmo meio de cultura, os halos variaram entre 8,0 e $14,0 \mathrm{~mm}$. No teste controle, que teve como base o fungicida DEROSOL ${ }^{\circledR}$, a variação foi de 17,0 a $36,0 \mathrm{~mm}$. No meio MRS, a variação foi de 13,0 a 35,0mm na presença de L. plantarum e de 18,0 a 41,0mm na presença de L. paracasei. No teste controle a variação foi de 18,0 a 40,0mm ( Tabela 1).

Tabela 1 - Atividade antagônica de bactérias láticas isoladas e identificadas frente frente à Fusarium guttiforme em meio BDA

\begin{tabular}{|l|c|c|c|c|c|c|}
\hline & \multicolumn{6}{|c|}{ Medida dos diâmetros dos halos (mm) } \\
\hline & I1 & I2 & I3 & I4 & I5 & I6 \\
\hline L.plantarum & $8,6 \pm 0,2$ & $11,0 \pm 0,1$ & $12,0 \pm 0,6$ & $12,0 \pm 1,5$ & $9,7 \pm 0,4$ & $10,0 \pm 0,5$ \\
\hline L. paracasei & $8,0 \pm 0,1$ & $14,0 \pm 0,1$ & $12,0 \pm 0,4$ & $9,0 \pm 0,1$ & $12,0 \pm 0,4$ & $10,0 \pm 0,6$ \\
\hline Controle & $33,0 \pm 0,6$ & $24,0 \pm 0,2$ & $17,0 \pm 0,1$ & $36,0 \pm 0,1$ & $30,0 \pm 0,2$ & $34,0 \pm 0,3$ \\
\hline
\end{tabular}

A atividade antimicrobiana das bactérias láticas pode estar relacionada à competição por nutrientes no meio, à produção de ácidos orgânicos como ácido lático e acético e a produção de compostos antagônicos como peróxido de hidrogênio e bacteriocinas. (FRANCO, 2010).

\section{CONCLUSÃO}


Através deste trabalho, observou-se o potencial antagônico de bactérias láticas frente ao Fusarium guttiforme, demonstrando também a eficácia da técnica de difusão em disco na realização do teste de ação antimicrobiana para esta finalidade. Desta maneira, a utilização de bactérias láticas no controle biológico constitui-se uma ferramenta muito promissora para o tratamento da fusariose do abacaxizeiro, visto que propõe a minimização da utilização de agentes químicos prejudiciais à saúde em plantações de abacaxi, promove equilíbrio ao meio ambiente e gera menores custos para a produção do abacaxi.

\section{REFERÊNCIAS}

CRESTANI, Maraisa et al. Das Américas para o Mundo origem, domesticação e dispersão do abacaxizeiro. Cienc. Rural [online]. 2010, vol.40, n.6, pp. 1473-1483.

CORSETTI, A. et al. Antimould activity of sourdough lactic acid bacteria: Identification of a mixture of organic acids produced by Lactobacillus sanfrancisco CB1. Applied Microbiology and Biotechnology, v.50, p253-256, 1998.

CUNHA, G.A.P.; CABRAL, J.R.S.; SOUZA, L.F.S.; 0 Abacaxizeiro. Cultivo, agroindústria e economia. Embrapa Mandioca e Fruticultura (Cruz das Almas, BA). Brasília: Embrapa Comunicação para Transferência de Tecnologia, 1999. p.17- 480.

FRANCO, T. S. Bactérias láticas no biocontrole Fusarium graminearum e na detoxificação de desonxinifalenol, 2010. 108 f. Dissertação (Mestrado em Ciências de Alimentos) - Universidade Estadual de Londrina, 2010.

MATOS, A. P. DE; CABRAL, J. R. S. Manejo integrado da fusariose do abacaxizeiro. Cruz das Almas: Embrapa-CNPMF, 2005. 2p. (Embrapa-CNPMF, Abacaxi em Foco n. 32).

MICHEREFF, S. J. Fundamentos de Fitopatologia Recife, 12 de fevereiro de 2001, 133p.

NIRENBERG, H. I.; O'DONNELL, K. New Fusarium species and combinations within the Giberellafujikuroi species complex. Mycologia, v. 90, p. 434-458, 1998.

SOUSA, Aline Ellen Duarte de. Atividade antifúngica de óleos vegetais no controle de podridão-por-fusarium em melão e fusariose em abacaxi. 2010. 81f. Dissertação

(Mestrado em Agronomia: Fitotecnia) - Universidade Federal Rural do Semi-Árido (UFERSA), Mossoró, 2010. 